\title{
Editorial
}

\section{El imperio del mal}

\author{
Javier Divar Garteiz-Aurrecoa \\ Catedrático Emérito de la Universidad de Deusto \\ Presidente de la Asociación Internacional de Derecho Cooperativo
}

Cualquier persona bien informada, conocedora de los sistemas económicos, puede preguntarse en buena lógica por la razón por la que las sociedades avanzadas no han desarrollado sistemas alternativos al capitalismo, e incluso han abandonado los viejos modelos solidaristas, mutuales y cooperativos, considerados como propios del utopismo redentorista del siglo XIX, ya que el antaño calificado como «capitalismo salvaje» ha tenido la inteligencia de ir limando sus peores aristas y ha sabido adecuarse a la evolución de los tiempos para aparecer como «sistema único», en el «fin de la historia».

En efecto, habiéndose consolidado en las naciones desarrolladas la democracia y las asistencias sociales, no se entiende bien cómo el cooperativismo, por ejemplo, no ha llegado a ser, después de dos siglos, una auténtica alternativa económica, siendo el movimiento cooperativo el origen de la llamada democracia económica y de la economía social.

Ciertamente los movimientos alternativos no han sabido transmitir con globalidad sus valores y han sido torpes en la utilización de la información, frente a la poderosa maquinaria de propaganda del capitalismo, que ha tenido el mérito de ver la utilidad de crear una cultura social afecta a sus intereses, desmoralizadora de las alternativas, tratando de imponer la creencia del «pensamiento económico único».

Pero en esencia, la causa principal del triunfo del capitalismo está en su engarce con las miserias de la naturaleza humana. Y fundamentalmente, aunque disfrazada mercantilmente como interés lucrativo, la codicia es la razón principal de ese éxito.

El desmedido afán de ganancia conduce directamente al egoísmo, a la desconsideración de los fracasados económicamente como «culpables» de su desgracia, como desvalidos por su falta de mérito.

Ello trae también como consecuencia lógica el triunfo en nuestras sociedades del individualismo, cada vez más alejadas de los valores humanistas, calificados como propios de ilusos y de débiles (en una imagen generalizada de la "selva económica», donde sólo pueden sobrevivir los grandes depredadores mercantiles, los más listos, los más eficaces, los más crueles). Así, sin apenas percibirlo, vamos cayendo en 
una especie de «nazismo económico», si se me permite la odiosa comparación.

Históricamente el fin lucrativo se convirtió incluso en virtud moral de los emprendedores y en bien religioso, considerado ya como tal por las posiciones calvinistas del reformismo religioso (impulsoras, según Max Weber, del llamado «espíritu capitalista»), que terminó por incardinarlo como un valor social.

Al fin todo queda justificado por una buena cuenta de resultados, amparándose la gestión económica en la consecución del reparto de las ganancias, como botín de los socios mercantiles (en una actualizada «patente de corso» de los tiempos modernos, ahora bajo la legitimación del ordenamiento jurídico).

El lucro, motor del insaciable poder económico global, es causa del materialismo capitalista, condenado por las doctrinas sociales cristianas por distanciarse de los valores morales y humanistas.

Si la esencia de la calificación como «imperio del mal» del comunismo (Reagan dixit) fue precisamente su marcado carácter materialista, también debemos concluir que el capitalismo es indubitablemente materialista.

Además, el capitalismo excluye a la mayoría de la población de los beneficios económicos (puesto que no detentan participaciones en las sociedades mercantiles). El resultado es el creciente abismo entre ricos y pobres, debido a la lógica económica de la acumulación de los primeros como receptores de los dividendos.

Los trabajadores en cambio no tienen más bien económico que su trabajo, al que es fácil rebajarle de sus derechos, ante su calificación mercantil como coste empresarial, en cuanto las crisis económicas empobrecen las cuentas de resultados y las expectativas de inversión por el descenso de los dividendos societarios.

Por contra, como hemos visto tantas veces, esos mismos argumentos son de utilidad para apoyar a los sectores estratégicos (banca, finanzas, energéticos, ...) mediante ayudas y subvenciones, con desvíos presupuestarios que penalizan a los sectores de población más necesitados, que terminan por hundirse en la pobreza extrema.

También es una clara rémora de las sociedades capitalistas la falta de participación de los trabajadores, lo que implica una esquizofrenia del sistema, que predica la democracia política (que entre otros logros le facilita su seguridad jurídica) pero niega la económica. Ello provoca la desconfianza de muchos ante los sistemas democráticos, vistos como un nuevo "opio del pueblo», propio para la acomodación y el adormecimiento en un sistema social injusto. A la larga un grave peligro para la estabilidad de las sociedades avanzadas. 